\title{
A Feminine Subject in Postmodernist Chaos: Janette Winterson's Political Manifesto in Oranges are not the only Fruit
}

\author{
Mónica Calvo Pascual \\ University of Zaragoza \\ mocalvo@teleline.es
}

\begin{abstract}
This paper intends to explore Jeanette Winterson's novel Oranges Are Not the Only Fruit (1985) in its reconciliation of postmodernist notions of identity, formal experimentation, and political commitment from the margins of patriarchal society. For this purpose, I shall focus first on Winterson's position with respect to different postmodernist topics and polemics that she deploys so as to reinforce the political agenda that lies behind the writing of the novel. Then, I shall try to unravel how the novel is structured as a chaotic system constituted by several layers of signification whose interaction creates infinite patterns of interpretation. Finally, I shall put forward how this postmodernist antitotalizing narrative strategy recalls in its functioning and implications the kind of writing proposed by French feminists such as Luce Irigaray and Hélène Cixous as the essentially "feminine" expression, in order to conclude that it is this chaotic structure that allows Winterson to provide a space for a female subject defined not in polar opposition to "man" but in her own "feminine", postmodernist terms.
\end{abstract}

Postmodernist literature is characterized, among others, by two distinctive features. The first is the radical loss of belief in and recurrent attempts to deconstruct both the traditional master narratives upon which Western thought is based and the idea of the "bourgeois individual subject" as a unified stable entity - "which is denounced [by Fredric Jameson and 
other analysts of postmodernism] as one of the most widespread artificial constructions of the patriarchal system, of realistic fiction and of the Western world view at large" (Onega, 1995: 139). And the second, the struggle of social groups marginalized by the dominant "andro- (phallo-), hetero-, Euro-, ethno- centrisms" (Hutcheon, 1988: 61) for a space in cultural expression and social recognition.

Critics and writers frequently consider the reconciliation of these two defining aspects of the postmodernist age as difficult in their very nature. As Patricia Waugh argues in her chapter "Postmodernism and Feminism: Where Have All the Women Gone?" (1989: 1-33), women writers, like all other previously silenced groups, feel the need to reassert the viability of their sense of identity if they want to acquire the strength and consistency necessary to subvert their imposed decentralization. Thus, Waugh goes on, women writers find themselves at odds with the dominant (male, she adds) postmodernist ideology that uses and abuses formal experimentation so as to do away with any trace of totalizing, authoritative conceptions of subjectivity and master discourses.

Within this context, Jeanette Winterson's Oranges Are Not the Only Fruit (1985) sets out to explore, redefine and reassert the notion of the individual subject from the position of its autodiegetic narrator ${ }^{1}$, Jeanette, who is doubly "ex-centric" (cf. Hutcheon, 1988: 5773) because female and homosexual, while upholding a perspective that is postmodernist in both formal and ideological terms. Winterson develops her semi ${ }^{2}$ "autobiographical comedy of coming out" (Onega, 1995: 135) in the frame of a rewriting of the first eight books of the Old Testament. As usual in much postmodernist writing, Winterson engages in a subversion of a master narrative through parodic revision -she works from within the foundations of patriarchal thought that she intends to undermine by transforming them into the bases of her lesbian political manifesto.

In keeping with her intention to deconstruct the validity of (sacred) history, Winterson embarks on an explicit reflection on the nature of the category "history" and its relation with that of "stories" in the central chapter: "Deuteronomy. The last book of the law" (1996: 9193). In this chapter, Winterson denounces the "reducing of stories called history" (p. 91) as the end-product of a series of manipulations of past events "until it looks the way you think it should" (p. 92) so that people "know what to believe and what not to believe" (p. 91) and can be "kept where they belong" (p. 92). This absolutist maneuver of privileging the story told from the hegemonic point of view over all the Others is, according to Winterson, "a means of denying the past" (p. 92) and of silencing those Other discordant voices that might destabilize the power of the dominant social groups. The narrating voice launches a further attack on the authority of any official history in her defense of the importance of being aware of the subjectivity and relativity of perspective inherent in every account of "reality":

Perhaps the event has an unassailable truth. God saw it. God knows. But I am not God. And so, when someone tells me what they heard or saw, I believe them, and I believe their friend who also saw, but not in the same way, and I can put these accounts together and I will not have a seamless wonder but a sandwich laced with mustard of my own (p. 93; emphasis added). 
Jeanette goes on with a piece of advice that stands as a metaphor for her overall purpose to rewrite sacred history from her lesbian perspective as a way of palliating the difficulty for the lesbian subject to build her identity after a model, since the dominant discourse has invariably muted every possible lesbian voice and story ${ }^{3}$ : "if you want to keep your own teeth, make your own sandwiches [for] if you always eat out" -swallowing the official "reducing of stories called history" - "you can never be sure what's going in" (p. 93; emphasis added).

The narrator's democratic defense of difference, already expressed in the existence of multiple stories that challenge totalitarian uses of history, is reinforced by her frequent allusions to the changeability of "reality" depending on one's perspective. One example would be Jeanette's reinterpretation of Elsie's wooden representation of "Shadrach, Meshach and Abednego in the fiery furnace" as "Pentecost" (p. 31). Another, Jeanette's explanation of how people interpret things according to expectation and "panic [...] when confronted with something they don't understand" (p. 44) ${ }^{4}$. The inescapably partial and relative quality of perception is metaphorized in the dream Winnet -Jeanette's alter ego in a different narrative level- has: sitting on a roundabout horse, Winnet becomes aware of the fact that she sees the same things differently "every time she goes round" (p. 155).

Another important element in "Deuteronomy" that reappears in other chapters is the way the narrator rereads T. S. Eliot's conception of time as developed in Four Quartets (1944). Winterson's revision brings about not a sense of perfect integration and eternal present, as the poet presumably intended, but rather a view of human identity as diffused and disintegrating, as the following passage makes explicit:

I have a theory that every time you make an important choice, the part of you left behind continues the other life you could have had. [...] I might be anywhere at one time, influencing a number of different things [...]. There's a chance that I'm not here at all, that all the parts of me, running along all the choices I did and didn't make, for a moment brush against each other. That I am still an evangelist in the North, as well as the person who ran away. Perhaps for a while these two selves have become confused. I have not gone forward or back in time, but across in time, to something I might have been, playing itself out (p. 164). ${ }^{5}$

This idea of the fragmentation and proliferation of human identity and existence may be seen, in turn, as a metaphysical correlate of the structural construction of Oranges. In her introduction to the novel Winterson explained in 1991 that

Oranges is an experimental novel: its interests are antilinear. It offers a complicated narrative structure disguised as a simple one. [...] You can read in spirals. As a shape, the spiral is fluid and allows infinite movement. But is it movement backwards or forwards? Is it height or depth? Draw several, each drifting into each and all this will be clear. [...] Every turning yields another turning, not symmetrical, not obvious. Not chaos, either. A 
sophisticated mathematical equation made harder to unravel because $\mathrm{X}$ and $\mathrm{Y}$ have different values on different days. (xiii; emphasis added).

If one pays attention to the chronological structure of the novel, the tracing of its temporal leaps -mainly analepses as the autodiegetic narrator remembers things previous to the story time, and prolepses advancing events or ideas she will develop later ongraphically shows a series of asymmetric spirals. Besides, these may be seen as interacting at a different scale with other spirals described by the superimposition of the different narrative and ontological levels in which the story is arranged. Just to mention a few of the many examples of temporal leaps in the otherwise linear narration, Jeanette's encounter with a gypsy who tells her that she will never marry (p. 7) is recalled when she becomes glad about this prediction on account of her dislike of Pastor Finch (p. 16). The gypsy's words in "Genesis" lead Jeanette to mention "the two women who ran the paper shop" and "dealt in unnatural passions" (p. 7), whose significance will be developed when they reappear three chapters later, in "Numbers" (pp. 75, 83). There is a considerable flashback in "Exodus" to recount the funny episode of seven-year-old Jeanette's temporary deafness -or divine rapture, as her fanatic community believes (pp. 22-30). Furthermore, a remarkable prolepsis is embedded within this analepsis: suddenly deaf and misunderstood by everybody else, Jeanette is helped only by Miss Jewsbury, with whom she communicates by writing in a "Who to Contact in the Event of An Emergency" card that she takes from the post office (p. 26). This humorously advances Miss Jewsbury's more important help seven years later as she, a lesbian too, is the one who supports and gives shelter to Jeanette the night after her mother "denounces" the adolescent's lesbianism in the church (p. 104).

My point here is to argue that Oranges is indeed a chaotic novel, although in a sense different from the one to which Winterson seems to allude in her introduction ${ }^{6}$. For millennia, Western cosmogonies have invariably explained the origin of the universe as the result of a struggle between two opposite principles: the triumph of order over chaos. These interpretations were allied to the patriarchal rule which insistently associated order with positive (and male) values and chaos with corresponding negative (and female) ones, like disorder, confusion, anarchy and darkness (cf. Hayles, 1991: 2-3). However, the development of studies on the chaotic behavior of molecular systems in the scientific field of thermodynamics and the parallelisms later drawn by cultural and literary theorists between thermodynamic reactions and the functioning of metafictional texts have allowed for a reconceptualization of chaos not as sheer, fruitless disorder but as the source of a special kind of order manifested in an increasing level of complexity that develops and gains in coherence through spontaneous self-organization (cf. Hayles, 1991: 1, 6-7).

The research carried out by 1977 Nobel Prize Ilya Prigogine and Isabelle Stengers (1985: 246) has shown that molecular structures in equilibrium are constituted by a series of molecules that "behave independently of one another" - what they have called the "molecular chaos assumption" about the initiai conditions. Yet, when these molecules interact with some element from their environment, they enter a state of "nonequilibrium" and start colliding among themselves. In each collision, molecules bifurcate and the becoming matter produces correlations that arrange into ever-expanding fractal patterns along different scales, which keep on increasing through successive forkings that may go 
on ad infinitum. As Prigogine and Stengers (1985: 171, 246, 251) put it, "the system is structured as though each molecule were 'informed' about the overall state of the system" and the collisions "produce, as if by a preestablished harmony, an apparently purposeful behavior [that points] toward a transition from disorder to order." Establishing an analogy between thermodynamic and literary chaotic systems, Hayles (1991: 1) explains that "at the center of chaos theory is the discovery that hidden within the unpredictability of chaotic systems are deep structures of order. 'Chaos', in this usage, denotes not true randomness but the orderly disorder characteristic of these systems."

With these ideas in mind, it can be contended that Oranges is structured and behaves as a literary correlate of a thermodynamic molecular system in nonequilibrium conditions. The novel apparently develops along a main narrative axis: the autodiegetic narrator's account of her psychological, emotional and social evolution from seven-year-old girl to adult woman. Yet, this process of maturation, which follows the pattern of traditional Bildungsromane, is supplemented and given depth in perspective and scope by the insertion and superimposition of other narrative layers. This disposition of the material in apparently independent scales, together with frequent allusions -either explicit or implicit- to previous literary and historical texts, produces a series of parallelisms and interactions among the multiplicity of elements that provide a higher level of complexity to the overall result ${ }^{7}$. In this way, the realistic account of Jeanette's childhood in the first four chapters is enriched by the embedding of one nightmare and several fairy tales, in accordance with the small age of the focalizer, which function as mises-en-abyme éclatées ${ }^{8}$ that mirror the immediately preceding or following passages. In contrast, the last three chapters -after the break marked by the philosophical "Deuteronomy" - deal with the protagonist's passage through adolescence to youth and the Bildungsroman becomes a real tale of a heroine's quest for identity: Jeanette's struggle to accept her sexual orientation in spite of the reactionary religious education she has received, and to become strong enough to remain unaffected from external aggression when she reasserts her lesbian identity. The greater significance of these events is pinpointed by the shift in tone of the mises-en-abyme éclatées, as fairy tales give way to stories of a mythic and even legendary character. In all, there are fifteen mises-en-abyme éclatées along the novel, some of them in apparent isolation, like the story which little Jeanette invents around the figure of a personified tetrahedron (pp. 4748), her wedding nightmare (p. 69), or her summary of Beauty and the Beast (p. 70). The rest are overtly linked among themselves: the fairy tale about the prince that sought a flawless wife (pp. 58-65) is connected to Jeanette's vision of the Winter Palace (pp. 86-87) through the figure of the sacrificed goose. The story of the hunchback and the princess (pp. 9-10) is echoed by the triple mise-en-abyme about Winnet Stonejar and the sorcerer (pp. $137-144,148-149,154-155)$ in that they emphasize the teaching of magic to an adopted daughter. And the latter is in turn linked to the mises-en-abyme in "Joshua" about the City of Lost Chances (pp. 108-109, 110-111) and the secret garden (p. 120) by the shared symbolism of the "chalk circle" in opposition to the "stone wall." Finally, the description of the secret garden is parallel to that of the Round Table (p. 127), linking the latter with the four mises-en-abyme about Sir Perceval (pp. 127, 132-133, 161, 168), which are connected 
to those about Winnet by the appearance of a raven that frees Sir Perceval from a spider thread in a dream (p. 168) -the same raven that helps Winnet and gives her "a rough brown pebble" (p. 144), thus joining the symbolism of the "chalk circle", drawn with "a rough brown pebble" (p. 139), and the realistic account of Jeanette's development, who feels tied to her mother by an invisible thread (p. 171).

The implications that can be extracted from such an accumulation of narrative scales and the various interconnections that link them $\mathrm{m}^{9}$-like the points where molecules collide and diverse spirals intersect-, together with the suggestive power of apparently simple passages whose connotative richness adds different nuances to the overall purpose of the text ${ }^{10}$, may allow for striking, unexpected readings of the novel that will depend on the reader's capacity to decode the implicit information. As Prigogine and Stengers' studies reveal,

all systems contain subsystems, which are continually "fluctuating." At times, a single fluctuation or a combination of them may become so powerful, as a result of positive feedback [in the decoding process], that it shatters the preexisting organization. [In this way,] order and organization can actually arise "spontaneously" out of disorder and chaos through a process of "self-organization." (1985: xv; emphasis added).

For instance, the apparently simple, straightforward paragraph recounting Jeanette's adoption introduces two lines of implications that will link different narrative levels along the book and will weave into a supra-structural pattern of signification essential for the realization of the transcendence of the novel itself:

My mother [...] would get a child, train it, build it, dedicate it to the Lord. [...] She followed a star until it came to settle above an orphanage, and in that place was a crib, and in that crib, a child. [...] She said, "This child is mine from the Lord. "[...] Her flesh now, sprung from her head (p. 10).

The last sentence clearly brings to mind the birth of goddess Athena from Zeus's head in Greek mythology. This image has a twofold implication: On the one hand, Athena was the virgin warrior goddess. Her main characteristics were that she, like Jeanette, had no sexual or emotional contact with male gods or heroes and that she played a central role in the institution of war, reserved for the male -just as Jeanette in the church-, where she took charge of the intellectual matters and used quasi-magical means (cf. Madrid, 1991: 9599). On the other hand, the association of Jeanette's mother with Zeus has important consequences: according to Hesiod in his Theogony, the most important divinity in preOlympic mythology was Gea, an ungendered entity that represented the order that put an end to initial universal chaos and confusion. Yet, in the establishment of Olympic mythology and patriarchal dominance, Gea was assigned female gender and came to represent primal chaos. In contrast, the figure of Zeus was created and allied to the concept of cosmos or order. And it is upon the struggle and final triumph of Zeus over Gea that the supremacy of both Olympic order and male values were founded (pp. 9-39). Thus, Jeanette's mother - a stern representative of Christian religious discourse- is set up in her 
association to Zeus not only as responsible for the imposition of gender difference, but also as the defender of patriarchal supremacy in a hierarchical society based on unavoidably discriminating dualities.

Even more outstanding is the way in which the quoted paragraph establishes a parallelism between Jeanette's adoption and Jesus Christ's birth: a star guides Jeanette's mother toward the child she will adopt, just as a star led the Three Wise Men to the stable where Jesus was born in Bethlehem according to the sacred scriptures. The association of Jeanette with Jesus Christ can be traced as a "recursive symmetry" along different narrative scales throughout the book and it is only in the interaction of realistic account, fairy tale and mythic story that the overall pattern acquires full significance. To start with, the embedded tale about the hunchback who adopted "a brilliant and beautiful princess" and taught her magic so that she could take care of their village (pp. 9-10) precedes and parallels the account of Jeanette's mother's wish that she learn the Ola Testament and become a missionary (p. 10). The symmetry between the two stories is reinforced in the last chapter, in the mythic tale of Winnet Stonejar - one of Jeanette's alter egos. In this case, the sorcerer who adopts Winnet teaches her "the magic arts" so that she can "take the message to other places, where they hardly know how to draw a chalk circle" (p. 139), just as Jeanette's mother wanted her daughter to carry God's message to the heathen. Yet, as happens to Jeanette, Winnet is forced to leave the castle when she falls in love with a person the sorcerer does not accept. This mirrors a turning point in the protagonist's selfunderstanding: the raven Abednego tells Winnet that she won't lose her power, she will "just use it differently" (p. 143), before vomiting "a rough brown pebble" (p. 144) -doubtlessly, the most recurrent motif in the novel. Referring to the pebble, Abednego says: "It's my heart. [...] You see I chose to stay [...] and my heart grew thick with sorrow, and finally set. It will remind you" (p. 143). Two significant details are essential here: for one, the names of the three ravens in the sorcerer's castle are the same as the mice's in Elsie's wooden representation of the fiery furnace, which Jeanette identified with "Pentecost" (p. 31). And second, "a rough brown pebble" is also the reminder left for Jeanette by "the orange demon that beguiles", which helps her decide whether she is to declare or hide her lesbian identity in the realistic narration (p. 128). These connections or "recursive symmetries" establish an ironic reversal of the mother's expectations that is depicted as a moment of Pentecostal revelation: the protagonist's knowledge of the Old Testament turns out to be the magic tool she will use in order to take care of her people -the lesbian community - through the writing of the novel - i.e., by offering her special message about lesbian existence and by rewriting the patriarchal text whose fanatic readers made her childhood so difficult. The associations are reinforced by the narrator's statement that "I could have been a priest instead of a prophet. [...] The prophets cry out because they are troubled by demons. This ancient city is made of stone and stone walls that have not fallen yet" (p. 156) -and it is her task to knock them down. The parallelism between Jeanette as an open lesbian committed to the task of consciousness raising and the prophet par excellence is finally corroborated in the nearly identical descriptions of the walled secret garden (p. 120) and the Round Table (p. 127). The orange tree of conformist comfort that 
stood in the middle of the former becomes "a thorny crown"11 in the latter as soon as Sir Perceval (Jeanette's mythical alter ego) "comes out" in his quest for the Holy Grail.

There is a recurrent play in the different levels of the novel with the image of the "stone wall" as opposed to the "chalk circle." The chalk circle is depicted as a protective space which lesbian subjects have to create for becoming strong enough to "come out." Once within this space, the narrator says, they can "push out their power bit by bit, first within their hearts, then within their bodies, then within their immediate circle" (p. 137). In opposition, the "stone wall" is a negative image, a metaphor for the gay closet $^{12}$ : "Walls protect and walls limit. It is in the nature of walls that they should fall. That walls should fall is the consequence of blowing your own trumpet" (p. 110). The narrator seems to suggest the acquisition of a voice and assertion of one's identity as the means for conquering the Promised Land -happiness and a place in society. In fact, Jeanette's indecision between staying in or coming out of the closet develops in "Joshua", a lesbian re-writing of "The Book of Joshua", which tells the story of the Israelite occupation of Canaan -the Promised Land- at a time when the people of Israel were exiles in Babylon. Her psychological troubles are further explored in her dream about "the City of Lost Chances", where the people who deny their sexual identity -"those who chose the stone wall"- end up "mutilated", "prisoners" in "a massive stone turret" (pp. 110, 108-109; emphasis added).

Jeanette's message, embodied in Winterson's novel, therefore, amounts to a reflection on the issues of lesbian identity and "coming out" accompanied by several ideas developed by lesbian cultural criticism. The narrator explicitly states that she has "a number of notions about sexual politics" (p. 126) and about lesbian literature before blaming the congregation's views on "Inversion" to their reading of "Havelock Ellis" (p. 126). Narratorial irony is remarkable when Jeanette attacks both heterosexist inability to see sexual sameness ${ }^{13}$ as a source of attraction and the conflation of the categories "sex", "gender" and "sexual orientation" brought about by this blindness, when she states that "a homosexual is further away from a woman than a rhynoceros" (p. 126). And even more so, when she considers her mother's idea that, having usurped a male role by preaching in the church, "I had flouted God's law and tried to do it sexually. [...] So there I was, my success in the pulpit being the reason for my downfall. The devil had attacked me at my weakest point: my inability to realize the limitations of my sex" (pp. 131-132). The selfconsciousness of the novel about its political agenda is most conspicuous in the way it repeatedly inscribes within the fiction some of the main tenets put forward by Adrienne Rich in her seminal work "Compulsory Heterosexuality and Lesbian Existence", first published in 1980. The fairy tale about the prince who wanted to marry a flawless woman echoes Rich's notion of male fear of clever, independent women: the chosen woman is beheaded ${ }^{14}$ when she refuses to marry him because, as the prince's advisor warns him, otherwise "your kingdom [the patriarchal system] is at stake" (63). The issues of marriage and compulsory heterosexuality are further tackled in the narrator's pondering about the children's tale Beauty and the Beast as an example of the "control of consciousness" exerted by the "idealization of heterosexual romance and marriage" in literature, film and the media as "covert socializations [...] which have channeled women into marriage and heterosexual 
romance" (Rich 1993: 234, 231). Fourteen-year-old Jeanette finds out that women are the unaware victims of "a terrible conspiracy" (71), as they are cheated by tales of the sort into marrying beasts that never become handsome princes: "I wondered if the woman married to a pig had read this story. She must have been awfully disappointed if she had" (70). There is also criticism of the heterosexist association of love and sex exclusively with the reproduction of the species, an association which posits heterosexual identifications as the only possible, natural ones: "There were a lot of women, and most of them got married. If they couldn't marry each other, and I didn't think they could, because of having babies, some of them would inevitably have to marry beasts" (71; emphasis added). Another issue tackled in these passages is Catherine A. McKinnon's denunciation of "the daily "erotization of women's subordination'" (in Rich 1993: 235) in Jeanette's conversation with her uncle Billy: "'Why are so many men really beasts?' [...] 'You wouldn't love us any other way,' he said, and rubbed his spiky chin against my face. [...] 'You hurt me,' I accused. 'No I didn't,' he grinned. 'It was just a bit of love'" (71-72).

In addition, the novel acquires a comic tone through the introduction of episodes and punch lines that act as bathetic plunges after the narration of dramatic situations. For instance, when little Jeanette believes that the paper shop women's dealing in "unnatural passions [...] meant that they put chemicals in their sweets" (7). Similarly, the girl's traumatic experiences in school, caused by her apocalyptic obsessions from too much Bible reading, are counterbalanced by her conclusion after reading "Deuteronomy" that "I was glad I didn't have testicles. They sounded like intestines only on the outside, and the men in the Bible were always having them cut off [...]. Horrid." (41). Winterson's emphasis on humor may be seen as a contrast to the usual pathos of lesbian fiction. As Rich puts it,

We romanticize at our peril what it means to love and act against the grain, and under heavy penalties; and lesbian existence has been lived [...] without access to any knowledge of a tradition, a continuity, a social underpinning. The destruction of records and memorabilia and letters documenting the realities of lesbian existence must be taken very seriously as a means of keeping heterosexuality compulsory for women (1993: 239).

Jeanette's mother's burning of the letters, cards and jottings written by Jeanette and her girlfriend (110) echoes Rich's words concerning the fact that the lesbian "past has been "erased,' obliterated by the actions of a hostile society" (Zimmerman, 1993: 41) and thus made unavailable for any possible reconstruction of a "lesbian her/story."

A definitive, straightforward attack upon religious discourse against homosexuality is launched when the narrator, focalizing through fourteen-year-old Jeanette, states: "We [Melanie and Jeanette] read the Bible as usual, and then told each other how glad we were that the Lord had brought us together" (86; emphasis added).

Feminist cultural critics like Teresa De Lauretis have recently studied "the gender dimension of narrative structure", concluding that the masculine element is always represented as "active and mobile" and the female as "passive and inert" (in Farwell, 1992: 94). This interest has been followed by a related question posed by lesbian critics: if the "narrative structure that identifies narrative space in gendered terms [...] also reinforces 
heterosexuality" (95), how can female desire be encoded in a narrative structure in woman's own terms and for her own ends? My contention is that the chaotic structure of Oranges allows Winterson to escape this gender binarism and to encode female desire and subjectivity, while making lesbian feminist claims and essentialist views on feminine writing and sexuality compatible with postmodernist tenets and formal experimentation. To begin with, the multiple levels that constitute the chaotic structure are all interconnected and each implies and is implied by the others, so that

Chaos brings a new challenge to the reductionist view that a system can be understood by breaking it down and studying each piece [...]. The interaction of components on one scale can lead to complex global behavior on a larger scale that in general cannot be deduced from knowledge of the individual components (Paulson, 1991: 45).

A chaotic text is thus "an open system, never completely decipherable or interpretable [whose meaning] is impossible to recover unambiguously" (Paulson, in Porush, 1991: 78), since each possible reading depends on "positive feedback" in the decoding process of textual elements and all their possible large-scale implications. As Peter Stoicheff (1991:87) explains, "by eternally adapting to new interpretations", a chaotic text "defeats closure", producing "what Barthes terms the jouissance of an inexhaustible possibility of interpretations" that shatters any attempt at imposing a closed, stable meaning upon a text.

This proliferation of signification and the fact that it can never be totally controlled and contained brings to mind the somatic notion of "feminine writing" held by some essentialist French feminists like Hélène Cixous and Luce Irigaray. As a reaction against the repression of sexual difference and of female desire that is imposed after the acquisition of language when girls enter the realm of the Symbolic and the Law of the father in Lacanian theory, these writers and theorists propose a new kind of feminine writing-l'écriture fémininethat escapes patriarchal rigidity and repression as a means of expressing their selves in their own feminine terms. In this line, Cixous argues that masculine, Symbolic language is ruled by order and linearity as a consequence of male sexuality, which "gravitates around the penis, engendering that centralized body [...] under the dictatorship of its parts" (in Jones, 1986: 90). In contrast, Cixous points out, woman's writing, just as her sexuality spreads all over her body, proliferates and surpasses the limits of phallogocentric discourse: "Her writing can only keep going, without ever inscribing or discerning contours [...]. Her language does not contain, it carries; it does not hold back, it makes possible" (90), it "passes to infinity, [...] can never be theorized, enclosed, coded" (in Humm, 1992: 202, 200). In Irigaray's terms, "her language doesn't follow just one thread, one course, one pattern [...]. You speak from everywhere at the same time" (207; emphasis added).

Thus, the infinite proliferation of implications and connotations that spring from the symmetries and interactions between the different scales of the chaotic structure of Oranges may be interpreted as Winterson's strategy to accommodate the feminist contents of her novel in a kind of experimental and feminine expression that embodies feminine and lesbian desire -neither the writing nor the sexuality being reducible to masculine linearity and closed interpretation and control. This idea is reinforced by the implications of Winterson's 
description of the structure of the novel as a spiral - a recurrent motif in lesbian film iconography (cf. Dyer, 1990: 186). Therefore, since feminine writing is usually described as circular by essentialist feminist theorists, the lesbian spiraling writing may be considered as the most feminine means of expression, the spiral being a continuous superimposition of circles that gain in depth or height. And this involves a final challenge to the heterosexist accusation that lesbians are not real women and want to be men (cf. Wittig, 1993: 104).

Bearing in mind the above initial outline of the conflict between the deconstruction of old notions of identity and the ex-centrics' need to create new ones so that they can speak for themselves, Rosalind Ann Jones' words are illuminating when she states that

If women are to discover and express who they are, they must begin with their sexuality. [...] In the French context, it offers an island of hope in the void left by the deconstruction of humanism, which has been revealed as an ideologically suspect invention by men. If men are responsible for the reigning binary system of meaning -identity/other, $\mathrm{man} /$ nature, reason/chaos, man/woman- women, relegated to the negative and passive pole of this hierarchy, are not implicated in the creation of its myths (1986: 91; emphasis added).

In keeping with this contention, Jeanette Winterson adopts women's sexuality and writing in women's terms - beyond phallocentric dictatorship and influence- as the solid foundations for the construction of a new sense of identity free from patriarchal definitions in binary terms. As our reading of the novel shows, this achievement eventually enables women -especially lesbian women-to erect themselves as the speaking subjects of their own stories.

In conclusion, Oranges Are Not the Only Fruit may be interpreted as a reconciliation of postmodernist and feminist terets in that notions such as subjectivity as fragmented and proliferating, and the deconstruction of the dichotomy history/stories, fuse with the search for identity by an "ex-centric" writer and protagonist-narrator by means of the rewriting of the master narrative of Christian religious discourse as a lesbian political manifesto. This overall aim is achieved most significantly through an experimental, chaotic structuring of the material, in which French feminists' claims for an essentially feminine expression are embodied, creating, in turn, a space for a lesbian narrative that escapes the typical heterosexual conceptualization of narrative structure in binary gender terms.

\section{Notes}

1. I follow here, as elsewhere in this essay, the narratological terminology defined by Gérard Genette in Narrative Discourse. An Essay in Method,1987 (1983).

2. Winterson herself wrote in her introduction to the 1996 edition of the novel: "Is Oranges an autobiographical novel? No not at all and yes of course" (xiv).

3. The connection between the narrator's digression about the dichotomy history/stories and the notion of lesbian erasure in official history is made obvious in the protagonist's first girlfriend's words when they meet years after their affair. Melanie, now married to an army man and pregnant after being "brainwashed" into denying her lesbian identity, "said those sort of 
feelings were dead" (p. 166), just like the past events that history manipulates for its ends. The narrator responds, "'you can ill treat, alter and recolour what's dead. It won't complain'. Then she laughed and said we probably saw what had happened very differently anyway [...]. She laughed again and said that the way I saw it would make a good story, her vision was just the history, the nothing-at-all facts" (p. 166; emphasis added).

4. For example, the panic-stricken reaction of her fanatic religious community when they discover that Jeanette is in love with another girl.

5. Cf. Eliot: "What might have been and what has been/ Point to one end, which is always present. / [...]Or say that the end precedes the beginning,/ And the end and the beginning were always there/ Before the beginning and after the end./ And all is always now" (1959: 13, 19).

6. Winterson's a posteriori suggestion that Oranges should be read in spirals is inspiring for, precisely, it is "graceful, spiraling lines" that photographs of molecules undergoing a chaotic reaction show (cf. Nadeau, 1981: 18).

7. The wealth of intertextual references in Oranges Are Not the Only Fruit puts the text under analysis in a relation with the outside comparable to the relation between a molecular structure and the environment that surrounds it. In Prigogine and Stengers' words: "The interaction of a system with the outside world, its embedding in nonequilibrium conditions, may become [...] the starting point for the formation of new dynamic states of matter -dissipative structures, [which] correspond to a form of supramolecular organization" (1985: 143). Thus, the state of both molecular and literary systems in their interaction with others generates higher levels of supramolecular or supratextual complexity and coherence that eventually lead to the blurring of the dichotomy order/chaos.

8. Cf. Bal (1977; 107). This disposition of the mises-en-abyme in fragments scattered throughout the novel reinforces my view of Oranges as a multiple-scale chaotic structure.

9. According to Katherine Hayles, the key to "understand" a chaotic system is recursive symmetry: "A figure or system displays recursive symmetry when the same general form is repeated across many different length scales, as though the form were being progressively enlarged or diminished. [...] The repetition, if symmetrical configurations across multiple levels acts like a coupling mechanism that rapidily transmits changes from one scale level to another" (1991: 10-11; emphasis added).

10. According to Peter Stoicheff, in some passages, "from the chaos of the world outside itself, [a chaotic text] processes the smallest amount of information that is necessary to communicate it" (1991: 91).

11. A parallelism is drawn here between Jeanette?s and Jesus Christ?s passion.

12. In "Epistemology of the Closet", Eve Kosofsky Sedgwick elaborates her notion of the gay closet -i.e., either chosen or institutionally imposed silence about one's homosexual identity - as "the defining structure for gay oppression in this century", which produces in the closeted person feelings of "disempowerment and sheer pain" (1993: 48).

13. Lesbian perspective goes hand in hand with a postmodernist deconstruction of Cartesian dualities according to Toni A. H. McNaron's idea that "lesbians, by a simple but profound shift in our gaze of attraction, are positioned as thinkers and theorists poised to lead the way within the larger spheres of feminist thought toward a rejection of the very notions of either/or-ness" (1993: 296; emphasis added). For further discussion on heterosexist assumptions and same-sex desire, cf. Zimmerman (1993: 34) and De Lauretis (1993: 142). 
14. As Charles Perrault's tale "Bluebeard" (1694-1697) clearly warns the reader, beheading is the punishment reserved to independent and curious women. Without their heads women become the perfect objectified bodies of patriarchy's desire.

\section{Works Cited}

Bal, Mieke (1977): Narratologie (Essais sur la signification narrative dans quatre romans modernes). Paris: Klincksieck.

De Lauretis, Teresa (1993): "Sexual Indifference and Lesbian Representation." In H. Abelove, M. A. Barate and D. M. Halperin, eds., The Lesbian and Gay Studies Reader. London and New York: Routledge, 141-158.

Dyer, Richard (1990): Now You See It: Studies on Lesbian and Gay Film. London and New York: Routledge.

Eliot, T. S. (1959 [1944]): Four Quartets. London: Faber and Faber.

Farwell, Marilyn R. (1992): "Heterosexual Plots and Lesbian Subtexts: Toward a Theory of Lesbian Narrative Space." In K. Jay and J. Glasgow, eds., Lesbian Texts and Contexts. London: Onlywomen Press, 91-103.

Genette, Gérard (1987 [1983]): Narrative Discourse. An Essay in Method. Transl. by Jane E. Lewin. Ithaca, NY: Cornell University Press.

Hayles, N. Katherine (ed.)(1991): Chaos and Order: Complex Dynamics in Literature and Science. Chicago: University of Chicago Press.

Humm, Maggie (1992): Feminism. A Reader. London: Harvester.

Hutcheon, Linda (1988): A Poetics of Postmodernism. History, Theory, Fiction. New York and London: Routledge.

Jones, Rosalind Ann (1986): "Writing the Body: Toward an Understanding of l'écriture féminine." In E. Showalter, ed., New Feminist Criticism. London: Virago Press, 86-101.

Madrid Navarro, Mercedes (1991): La dinámica de la oposición masculinolfeminino en la mitología griega. Vol. 1. Madrid: M.E.C.

McNaron, Toni A. H. (1993): "Mirrors and Likeness: A Lesbian Aesthetic in the Making." In S. J. Wolfe and J. Penelope, eds., Sexual Practice, Textual Theory: Lesbian Cultural Criticism. Oxford: Blackwell, 291-306.

Nadeau, Robert (1981): Readings from the New Book on Nature: Physics and Metaphysics in the Modern Novel. Amherst: University of Massachusetts Press.

Onega Jaén, Susana (1995): " I'm Telling You Stories. Trust me": History/Story-Telling in Jeanette Winterson's Oranges Are Not the Only Fruit." In S. Onega, ed., Telling Histories. Narrativizing History, Historicizing Literature. Amsterdam: Rodopi, 135-147.

Paulson, William (1991): "Literature, Complexity, Interdisciplinarity." In N. K. Hayles, ed., Chaos and Order: Complex Dynamics in Literature and Science. Chicago: University of Chicago Press, 37-53.

Perrault, Charles (1939) [1694-1697]): "La Barbe Bleue." In Contes. Paris: Librairie Larousse, 48-54.

Porush, David (1991): "Fictions as Dissipative Structures: Prigogine's Theory and Postmodernism's Roadshow." In N. K. Hayles, ed., Chaos and Order: Complex Dynamics in Literature and Science. Chicago: University of Chicago Press, 54-84. 
Prigogine, Ilya and Isabelle Stengers: (1985 [1984]): Order Out of Chaos: Man's New Dialogue with Nature. London: Flamingo.

Rich, Adrianne (1993): "Compulsory Heterosexuality and Lesbian Existence." In H. Abelove, M. A. Barate and D. M. Halperin, eds., The Lesbian and Gay Studies Reader. London: Routledge, 227-254.

Sedgwich, Eve Sosofsky (1993): "Epistemology of the Closet." In H. Abelove, M. A. Barate and D. M. Halperin, eds., The Lesbian and Gay Studies Reader. London: Routledge, 45-61.

Stoicheff, Peter (1991): "The Chaos of Metafiction." In N. K. Hayles, ed., Chaos and Order: Complex Dynamics in Literature and Science. Chicago: University of Chicago Press, 85-99. Waugh, Patricia (1989): "Postmodernism and Feminism: Where Have All the Women Gone?." In Feminine Fictions. Revisiting the Postmodern. London: Routledge, 1-33.

Winterson, Jeanette (1996 [1985]): Oranges Are Not the Only Fruit. London: Vintage.

Wittig, Monique (1993): "One Is Not Born a Woman." In H. Abelove, M. A. Barate and D. M. Halperin, eds., The Lesbian and Gay Studies Reader. London: Routledge, 103-109.

Zimmerman, Bonnie (1993): "What Has Never Been: An Overview of Lesbian Feminist Criticism." In S. J. Wolfe and J. Penelope, eds., Sexual Practice, Textual Theory: Lesbian Cultural Criticism. Oxford: Blackwell, 33-54. 